\title{
Individual variation in fructose metabolism in man
}

\author{
By G. C. COOK* AND JANICE JACOBSON \\ Department of Medicine, The Royal Free Hospital, London, WC I \\ (Received 8 September 1970-Accepted I4 December 1970)
}

\begin{abstract}
1. Constant intravenous $(3 \mathrm{~h})$ infusions of a fructose solution were given on a rate for bodyweight basis $(0.6 \mathrm{~g} / \mathrm{kg}$ per $\mathrm{h}$ ) to thirty patients who had no evidence of diabetes mellitus or liver disease. Concentrations of blood fructose, pyruvate and lactate formed a plateau during the last $\mathrm{I}-\mathrm{r} \cdot 5 \mathrm{~h}$ of the infusion period.

2. Although the numbers were small, the individual pyruvate and lactate concentrations at plateau varied greatly and assumed a bi-modal distribution, suggesting two distinct groups. The group to show a lower pyruvate and lactate rise (group A) contained more males of a lower age and more patients who had ischaemic cardiac disease than the other group (B); none of these differences was, however, statistically significant. The fructose concentrations at plateau were not significantly different between the groups. Serum triglyceride glycerol concentration during the infusions rose markedly in three patients in group $A$ but in none in group B. Minor changes in concentration of blood glucose, insulin, inorganic phosphate and uric acid during the infusions were not significantly different between the groups and did not fall into a bi-modal pattern.

3. Constant intravenous $(3 \mathrm{~h})$ infusions of $0.15 \mathrm{M}$-sodium lactate at the same infusion rate in eight of the patients (four from group $A$ and four from group $B$ ) did not produce a significant difference in the blood lactate concentrations at plateau between patients from the two groups.

4. These results reflect qualitative differences in fructose metabolism in the patients studied. The difference in pyruvate and lactate production may be associated with total carbohydrate intake. However, the bi-modal distribution strongly suggests a genetically determined difference in metabolism between the two groups.
\end{abstract}

Sucrose and its constituent monosaccharide, fructose, are common dietary components of man in highly developed countries. It has been suggested that this high intake is related to the pathogenesis of coronary artery disease (Yudkin, 1967), possibly owing to its being associated with increased serum triglyceride concentration (Macdonald, 1968). It is now clear that most dietary fructose is absorbed into the portal circulation unaltered (Holdsworth \& Dawson, 1965; Cook, I969).

During the course of previous studies (Cook, I969, 1970), it has become clear that, during intravenous infusions of fructose in patients with normal liver function, there is a wide variation in the resulting blood lactate concentration. The investigation now described was designed to extend that observation.

\section{EXPERIMENTAL}

Subjects and their treatment

Thirty in-patients at The Royal Free Hospital agreed to take part in the investigation. They were randomly accepted for the study and none was diabetic or had evidence of liver disease; twenty-seven had biochemical tests of liver function (serum bilirubin,

- Present address: Department of Medicine, The University of Zambia, PO Box 2379, Lusaka, Zambia. 
aspartate transaminase, alkaline phosphatase, albumin, globulin and protein electrophoresis) which were normal. Table I summarizes their sex, ages, diagnoses and bodyweights; they are shown divided into two groups ( $A$ and $B$ ) because subsequent analysis of the results suggested that there was a difference in fructose metabolism between them. After a $10-12 \mathrm{~h}$ overnight fast, a $3 \mathrm{~h}$ intravenous infusion of a solution of fructose ( $10 \mathrm{~g} / 100 \mathrm{ml}$ ) (glucose concentration $<10 \mathrm{mg} / \mathrm{r} 00 \mathrm{ml}$ ) was made with a constant infusion pump at the rate of $6.0 \mathrm{ml}(0.6 \mathrm{~g}) / \mathrm{kg}$ per $\mathrm{h}$. Two samples of capillary and venous blood were taken $10 \mathrm{~min}$ apart before the start of the infusion and then at

Table 1. Sex, age, diagnosis and body-weight of the patients investigated

\begin{tabular}{|c|c|c|c|c|c|c|c|}
\hline \multirow[b]{2}{*}{ Group } & \multirow[b]{2}{*}{$\begin{array}{l}\text { No. } \\
\text { of } \\
\text { patients }\end{array}$} & \multirow[b]{2}{*}{$\mathrm{Se}$} & \multirow[b]{2}{*}{$q$} & \multirow[b]{2}{*}{$\begin{array}{c}\text { Age (years) } \\
\text { (mean and } \\
\text { range) }\end{array}$} & \multicolumn{2}{|l|}{ Diagnosis } & \multirow[b]{2}{*}{$\begin{array}{l}\text { Body-wt } \\
\text { (kg) (mean } \\
\text { and range) }\end{array}$} \\
\hline & & & & & Description & $\begin{array}{c}\text { No. } \\
\text { affected }\end{array}$ & \\
\hline A & 19 & 14 & 5 & $\begin{array}{l}45 \\
(21-73)\end{array}$ & $\begin{array}{l}\text { Ischaemic cardiac disease } \\
\text { Chronic bronchitis } \\
\text { Bronchial carcinoma } \\
\text { Cerebrovascular accident } \\
\text { (convalescent) } \\
\text { Chronic duodenal ulcer } \\
\text { Miscellaneous minor illnesses }\end{array}$ & $\begin{array}{l}5 \\
3 \\
1 \\
1 \\
1 \\
8\end{array}$ & $\begin{array}{l}68 \cdot 7 \\
(39 \cdot 4-97 \cdot 7)\end{array}$ \\
\hline B & II & 4 & 7 & $\begin{array}{l}55 \\
(2 x-76)\end{array}$ & $\begin{array}{l}\text { Ischaemic cardiac disease } \\
\text { Cerebrovascular accident } \\
\text { (convalescent) } \\
\text { Chronic duodenal ulcer } \\
\text { Obesity } \\
\text { Miscellaneous minor illnesses }\end{array}$ & $\begin{array}{l}1 \\
3 \\
2 \\
1 \\
4\end{array}$ & $\begin{array}{l}68 \cdot 4 \\
(51 \cdot 6-83 \cdot 2)\end{array}$ \\
\hline
\end{tabular}

intervals of $30 \mathrm{~min}$ for $3 \mathrm{~h}$. Urine obtained during the infusions and until $\mathrm{Ih}$ afterwards (i.e. a period of $4 \mathrm{~h}$ ) was immediately frozen solid. In eight patients (four from group A and four from group B) a constant intravenous infusion of 0.15 M-sodium lactate solution $(6.0 \mathrm{ml} / \mathrm{kg}$ per $\mathrm{h})$ was also given over a period of $3 \mathrm{~h}$ after an overnight fast of 10-12 h. Two venous blood samples were taken io min apart before the start of the infusion and then at intervals of $30 \mathrm{~min}$ for $3 \mathrm{~h}$. In an additional four patients, the effect of different concentrations of fructose solution given at the same rate (after an overnight fast) over two or three periods of $3 \mathrm{~h}$ on blood fructose and lactate concentrations was investigated. Two samples of capillary and venous blood were taken ro min apart before the start of the infusion and then at intervals of $30 \mathrm{~min}$ for $3 \mathrm{~h}$.

\section{Methods}

Fructose concentrations (capillary whole blood and urine) were estimated by an enzyme method (Klotzsch \& Bergmeyer, 1963). Capillary whole blood glucose concentrations were measured by a glucose oxidase method (Marks, 1959). Venous whole blood pyruvate (Bücher, Czok, Lamprecht \& Latzko, 1963) and lactate (Hohorst, 1963) were estimated by enzyme methods. Venous plasma insulin and serum uric acid concentrations were measured by immuno-assay (Hales \& Randle, 1963) and uricase (Praetorius, ${ }^{1963}$ ) methods respectively. Concentration of inorganic phosphate 
in venous serum was measured by the method of Fiske \& Subbarow (1925). Triglyceride glycerol concentration in venous serum was estimated by the glycerokinase method (Bell, Atkinson \& Baron, 1970). All estimations were done in duplicate. Capillary whole blood fructose and glucose, and venous blood lactate, plasma insulin, serum uric acid and inorganic phosphate concentrations were measured on the fasting samples and those taken at each time interval in all of the thirty patients who formed the main part of the investigation. Venous blood pyruvate concentration was estimated on the fasting samples and those taken at 60,120 and $180 \mathrm{~min}$, and serum triglyceride glycerol on the fasting samples and those taken at 120 and $180 \mathrm{~min}$. In the eight patients who had sodium lactate infusions, venous whole blood lactate was estimated on every sample. In the four additional patients, capillary whole blood fructose and venous whole blood lactate were estimated on every sample. Detailed dietary histories were obtained from twenty-three patients and these were based on a 6-month period before the present investigation.

\section{RESULTS}

Lactate. The mean of the lactate concentrations at $2,2 \cdot 5$ and $3 \mathrm{~h}$ after the start of infusion was taken in each individual patient (i.e. after a plateau had occurred). Fig. I shows a histogram of the results, which strongly suggests a bi-modal distribution and divides the patients into two groups ( $\mathrm{A}$ and $\mathrm{B}$ ). Fig. $2 a$ shows the mean values with their standard errors for these two groups at each estimation. Many more patients would have to be studied before a bi-modal distribution could be statistically proved (Fisher, 1946).

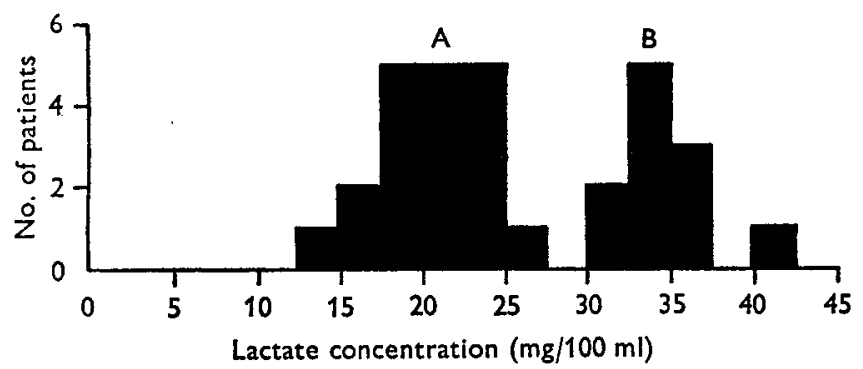

Fig. I. Histogram showing the concentration of whole blood lactate during intravenous infusion of fructose $(0.6 \mathrm{~g} / \mathrm{kg}$ body-wt per $\mathrm{h})$ in the nineteen patients in group $\mathrm{A}$ and eleven in group B (means of measurements made 2, 2.5 and $3 \mathrm{~h}$ after the commencement of the infusion).

Pyruvate. Fig. $2 b$ shows the mean values with their standard errors for the blood pyruvate concentrations for the two groups at each estimation. The concentrations closely followed the changes in blood lactate. When the mean is taken of the pyruvate concentrations at 2 and $3 \mathrm{~h}$ in each individual patient, the difference between the means for the two groups is significant $(t=5.15 ; n=23 ; P<0.001)$.

Fructose. Fig. $2 c$ shows the mean blood fructose concentrations in the two groups during the infusions. The differences between the means are not significant at any point. Urinary fructose excreted during the $4 \mathrm{~h}$ period from the beginning of the infusion was $1960(695-3672) \mathrm{mg}$ in group A and 2369 ( $1402-3000) \mathrm{mg}$ in group B. 
Glucose, insulin, inorganic phosphate, uric acid and triglyceride glycerol. Table 2 summarizes the fasting concentrations and Fig. 3 the changes from those concentrations during the infusions. None of the changes suggested a bi-modal distribution. Three patients in group A showed a rise greater than $5 \mathrm{mg} / \mathrm{roo} \mathrm{ml}$ in serum triglyceride glycerol concentrations; they were men of $2 \mathrm{I}, 30$ and 64 years; one had ischaemic cardiac disease, another a chronic duodenal ulcer and the third no organic abnormality.
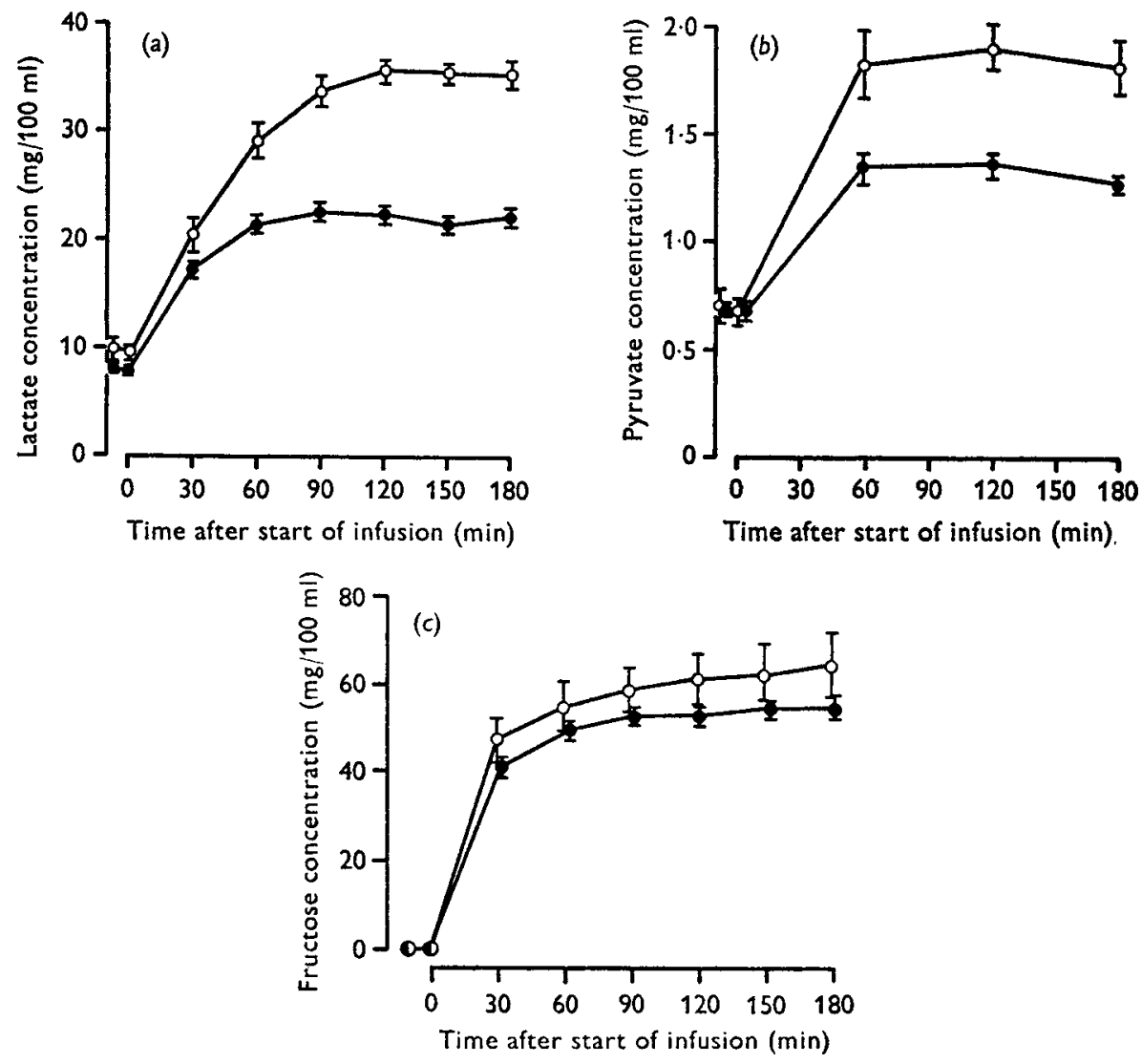

Fig. 2. Mean concentrations in whole blood of $(a)$ lactate, $(b)$ pyruvate and $(c)$ fructose in the nineteen patients in group $A(O)$ and eleven in group $B(O)$ during a $3 \mathbf{h}$ intravenous infusion of fructose $(0.6 \mathrm{~g} / \mathrm{kg}$ body-wt per $\mathrm{h})$. The vertical bars show the standard errors of the means.

The rises were from $\mathrm{I} \cdot \mathrm{r}$ to $7 \cdot 7$, from $8 \cdot 2$ to $18 \cdot 7$ and from 4.4 to $16.5 \mathrm{mg} / \mathrm{r} 00 \mathrm{ml}$ respectively; the former values are the means for the fasting samples and the latter the means of those at 2 and $3 \mathrm{~h}$. The normal fasting range is $2-18 \mathrm{mg} / \mathrm{100} \mathrm{ml}$.

Four patients from group $A$ and three from group $B$ had oral, and three others from each group had intravenous, glucose tolerance tests; all of these were normal.

Sex, body-weight, diagnosis and diet. The difference in the sex incidence between the two groups was not significant ( $\chi^{2}$ with Yates' correction $=2.64 ; P<0.20$ ) (Table $\mathrm{r}$ ). There was no relation between clinical obesity or body-weight and blood lactate concentration. Although group A contained five patients with ischaemic cardiac 
disease, and group B three patients with cerebrovascular accidents, these differences were also not significant. The estimated daily carbohydrate intake in group A was 180-402 (mean 294) $\mathrm{g}(n=14)$, and in group B 90-300 (mean 190) $\mathrm{g}(n=9)$; the difference between the means was significant $(t=3.19 ; P<0.01)$. Group A patients were estimated to take $23-298$ (mean 86 ) $\mathrm{g}$ and group B 4-140 (mean 45 ) g sucrose daily; the difference between the means was not significant $\left(t=I_{1} \cdot 42 ; P>0 \cdot 10\right)$.

Sodium lactate infusions. Table 3 shows the mean results for the blood lactate concentration at $2,2.5$ and $3 \mathrm{~h}$ after the start of the lactate infusions in the eight
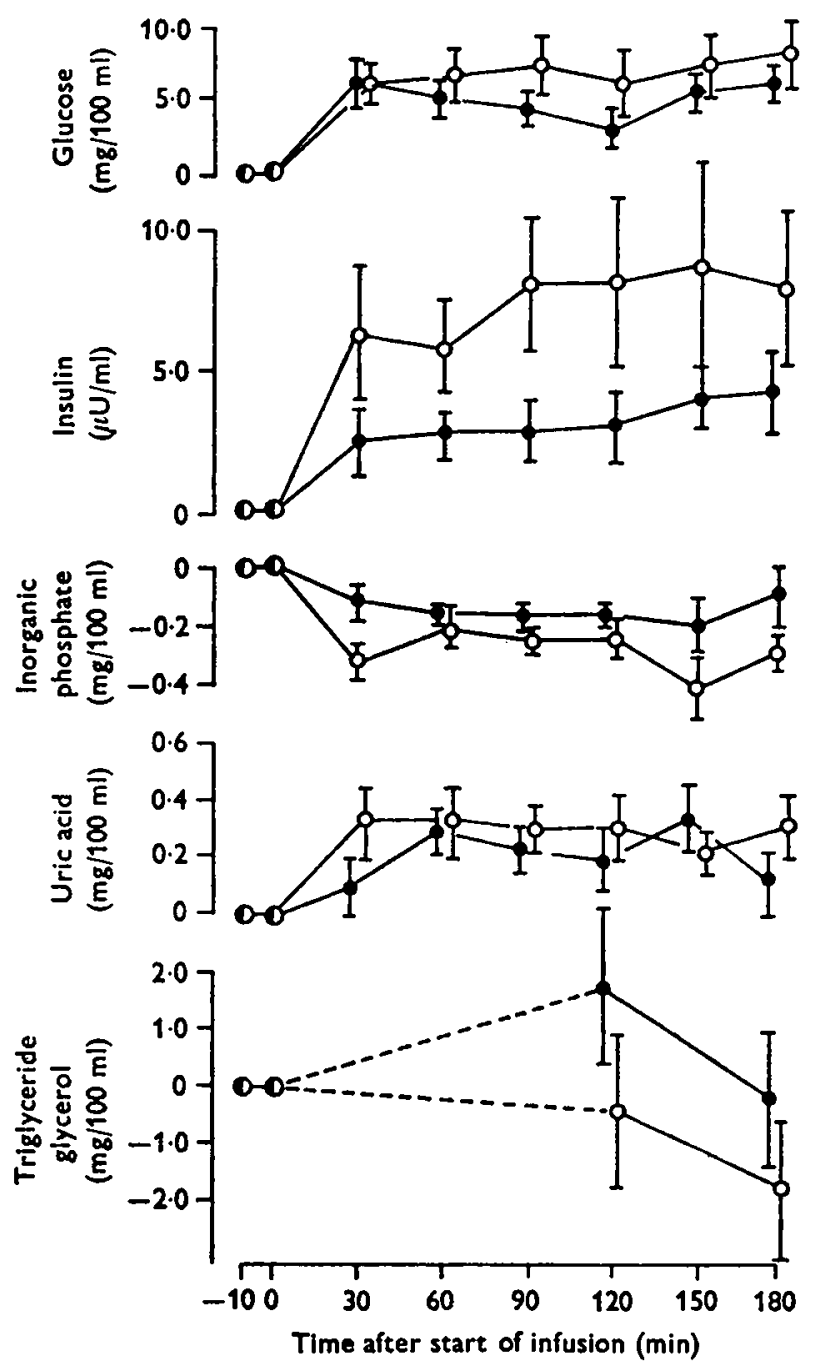

Fig. 3. Mean changes in concentration from the fasting values for whole blood glucose, plasma insulin, serum inorganic phosphate, uric acid and triglyceride glycerol in the nineteen patients in group $A(O)$ and eleven in group $B(O)$ during a $3 \mathrm{~h}$ intravenous infusion of fructose $(0.6 \mathrm{~g} / \mathrm{kg}$ body-wt per $\mathrm{h})$. The vertical bars show the standard errors of the means. The only significant difference between the two groups was in the mean insulin concentration at $90 \min (P<0.05)$. 
patients (four from group A and four from group B) studied. The concentrations were similar between the groups and did not suggest a bi-modal distribution.

Fructose infusion at two or more different concentrations. Table 4 shows the results for the mean rise in blood fructose and lactate concentrations at $2,2.5$ and $3 \mathrm{~h}$ after the

Table 2. Concentrations of fasting whole blood glucose, plasma insulin and serum inorganic phosphate, uric acid and triglyceride glycerol in the patients studied

(Mean values with their standard errors for nineteen patients in group A and eleven in group B)

\begin{tabular}{|c|c|c|c|c|c|}
\hline Group & $\begin{array}{c}\text { Glucose } \\
(\mathrm{mg} / \mathrm{r} \text { oo } \mathrm{ml})\end{array}$ & $\begin{array}{l}\text { Insulin } \\
(\mu \mathrm{U} / \mathrm{ml})\end{array}$ & $\begin{array}{c}\text { Inorganic } \\
\text { phosphate } \\
(\mathrm{mg} / 100 \mathrm{ml})\end{array}$ & $\begin{array}{c}\text { Uric acid } \\
(\mathrm{mg} / 100 \mathrm{ml})\end{array}$ & $\begin{array}{c}\text { Triglyceride } \\
\text { glycerol } \\
(\mathrm{mg} / 100 \mathrm{ml})\end{array}$ \\
\hline $\begin{array}{l}\text { A } \\
\text { B }\end{array}$ & $\begin{array}{l}62 \cdot 3 \pm 1 \cdot 5 \\
65 \cdot 1 \pm 1 \cdot 3\end{array}$ & $\begin{array}{l}22 \cdot 9 \pm 2 \cdot 0 \\
23 \cdot 9 \pm 2 \cdot 3\end{array}$ & $\begin{array}{l}3.6 \pm 0.1 \\
3.3 \pm 0.2\end{array}$ & $\begin{array}{l}4.5 \pm 0.2 \\
4.8 \pm 0.4\end{array}$ & $\begin{array}{l}I 4.2 \pm I \cdot 6 \\
16 \cdot 4 \pm 4 \cdot 0\end{array}$ \\
\hline
\end{tabular}

Table 3. Concentrations of whole blood lactate in individual patients during constant intravenous infusion of $0.15 \mathrm{M}$-sodium lactate

\begin{tabular}{|c|c|c|c|c|c|}
\hline \multirow[b]{2}{*}{$\begin{array}{l}\text { Patient } \\
\text { no. }\end{array}$} & \multirow[b]{2}{*}{ Group } & \multirow[b]{2}{*}{$\begin{array}{l}\text { Body-wt } \\
(\mathrm{kg})\end{array}$} & \multicolumn{3}{|c|}{ Whole blood lactate concentration $(\mathrm{mg} / \mathrm{r} 00 \mathrm{ml})$} \\
\hline & & & Fasting* & At plateaut & $\begin{array}{l}\text { Rise over fasting } \\
\text { value at plateau }\end{array}$ \\
\hline $\mathbf{I}$ & A & $81 \cdot 3$ & 7.7 & $13 \cdot 0$ & $5 \cdot 3$ \\
\hline 2 & A & $68 \cdot 0$ & $7 \cdot 9$ & $13 \cdot 6$ & $5 \cdot 7$ \\
\hline 3 & A & $61 \cdot 0$ & $9 \cdot 1$ & $16 \cdot 3$ & $7 \cdot 2$ \\
\hline \multirow[t]{2}{*}{4} & A & $62 \cdot 0$ & $7 \cdot 6$ & $22 \cdot 4$ & $15 \cdot 8$ \\
\hline & & Mean & $8 \cdot I$ & $16 \cdot 3$ & $8 \cdot 5$ \\
\hline 5 & $\mathbf{B}$ & $5^{8 \cdot 0}$ & $7 \cdot 8$ & 14.4 & $6 \cdot 6$ \\
\hline 6 & $\mathrm{~B}$ & $72 \cdot 0$ & $6 \cdot 9$ & I $6 \cdot 8$ & $8 \cdot 4$ \\
\hline \multirow{3}{*}{$\begin{array}{l}7 \\
8\end{array}$} & B & $70 \cdot 0$ & $8 \cdot 6$ & 20.4 & $11 \cdot 8$ \\
\hline & B & 73.0 & $17 \cdot 2$ & 24.4 & $7 \cdot 0$ \\
\hline & & Mean & $10 \cdot 1$ & 18.9 & $8 \cdot 4$ \\
\hline
\end{tabular}

- Mean of two samples taken at an interval of $10 \mathrm{~min}$.

+ Mean of lactate concentration at $2,2 \cdot 5$ and $3 \mathrm{~h}$ after commencement of infusion.

Table 4. Concentrations of capillary whole blood fructose and venous whole blood lactate during two or more fructose infusions at different concentrations in four additional patients

\begin{tabular}{|c|c|c|c|c|c|}
\hline \multirow[b]{2}{*}{$\begin{array}{l}\text { Patient } \\
\text { no. }\end{array}$} & \multirow[b]{2}{*}{$\begin{array}{l}\text { Body-wt } \\
\quad(\mathrm{kg})\end{array}$} & \multirow{2}{*}{$\begin{array}{l}\text { Infusion } \\
\text { rate } \\
(\mathrm{ml} / \mathrm{min})\end{array}$} & \multirow{2}{*}{$\begin{array}{l}\text { Concentration } \\
\text { of fructose } \\
\text { solution } \\
(\mathrm{g} / 100 \mathrm{ml})\end{array}$} & \multicolumn{2}{|c|}{$\begin{array}{l}\text { Rise over fasting concentration } \\
(\mathrm{mg} / \mathrm{1} 00 \mathrm{ml}) \text { at plateau } \dagger\end{array}$} \\
\hline & & & & $\begin{array}{l}\text { Whole blood } \\
\text { fructose }\end{array}$ & $\begin{array}{l}\text { Whole blood } \\
\text { lactate }\end{array}$ \\
\hline $\mathrm{i}$ & $76 \cdot 6$ & 5.7 & $\begin{array}{l}10 \\
20\end{array}$ & $\begin{array}{l}30 \\
8 \mathbf{r}\end{array}$ & $\begin{array}{l}25 \cdot 6 \\
45 \cdot 7\end{array}$ \\
\hline $\mathrm{ii}$ & $6_{3} \cdot 6$ & 7.4 & $\begin{array}{l}10 \\
20\end{array}$ & $\begin{array}{r}61 \\
130\end{array}$ & $\begin{array}{r}8 \cdot 4 \\
18 \cdot 7\end{array}$ \\
\hline iii & $52 \cdot 2$ & 5.5 & $\begin{array}{l}10 \\
20\end{array}$ & $\begin{array}{r}63 \\
169\end{array}$ & $\begin{array}{l}16 \cdot 2 \\
39 \cdot 7\end{array}$ \\
\hline iv & $56 \cdot 8$ & $5 \cdot 2$ & $\begin{array}{r}5 \\
10 \\
20\end{array}$ & $\begin{array}{r}23 \\
63 \\
124\end{array}$ & $\begin{array}{r}8 \cdot 3 \\
21 \cdot 5 \\
32 \cdot 0\end{array}$ \\
\hline
\end{tabular}


start of the fructose infusion in four additional patients (i-iv). At the fructose concentrations used for the infusions, there was an approximately linear association between the weight of fructose infused and the rise in both blood fructose and lactate concentration at plateau.

\section{DISCUSSION}

This investigation clearly shows that there is a marked individual variation in pyruvate and lactate production during $\mathrm{D}(-)$-fructose metabolism in man. The results strongly suggest a bi-modal distribution, but more patients would require to be studied for a statistical confirmation. A bi-modal distribution is not an uncommon finding in studies of drug metabolism in population groups (Price-Evans, 1969), but has not previously been reported in relation to a normal nutrient.

Although relatively large amounts of fructose were infused in this investigation, these were not excessive when compared with the estimated daily dietary intake of sucrose by some of our patients; fructose absorption is also very efficient (Cook, 1969). This investigation confirms that blood fructose concentration reaches a plateau $\mathrm{I} \cdot 5^{-2} \mathrm{~h}$ after the beginning of a constant intravenous fructose infusion (Smith, Ettinger, Seligson \& Lightcap, I953; Zöllner, Heuckenkamp \& Nechwatal, I968), and this has also been shown to apply to blood lactate. At the plateau an equilibrium state must have been reached between fructose uptake from the circulation and its metabolism in the liver, and to a far lesser extent in adipose tissue (Froesch, 1966).

Lactate clearance after the intravenous injection of lactate is rapid (Peters \& van Slyke, 1946; Pitts \& McClure, 1967). Our results from continuous infusions of lactate (Table 3) confirm this; they did not show a significant difference in lactate uptake (via pyruvate) between our two groups. The difference is not therefore a result of variation in incorporation of pyruvate into the citric acid cycle. Lactate concentrations at plateau in the same individual have been shown to have an approximately linear relation to the weight of fructose infused (Table 4); such a relationship has previously been shown for blood fructose at infusion rates varying from 0.5 to $1.5 \mathrm{~g} / \mathrm{kg}$ per $\mathrm{h}$ using a solution of fructose containing $10 \mathrm{~g} / 100 \mathrm{ml}$ (Zöllner et al. 1968).

Our results for blood lactate concentrations during the lactate infusions (Table 3) suggest that about half the infused fructose appeared as lactate in the circulating blood in group B and about a quarter in group A. Though the high blood concentrations of pyruvate and lactate are unlikely to be of pathological importance, they apparently reflect a qualitative difference in fructose metabolism between the two groups. It seems likely that more fructose was metabolized to pyruvate and lactate by the glycolytic pathway in group B than in group A, in which a considerable proportion disappeared from the circulation by another route. Although the difference was not statistically significant, three patients in group A showed a rise in serum triglyceride glycerol concentration during the infusions; this was possibly due to a greater extent of conversion of fructose into $\alpha$-glycerophosphate (Heinz, Lamprecht $\&$ Kirsch, I968; Zakim \& Herman, r968) and hence to triglyceride in the liver. The relation of the group A patients to those with carbohydrate-induced hyperlipaemia (Fredrickson, 
Levy \& Lees, 1967) has not been investigated. It is possible that our evidence indicating two populations with respect to fructose metabolism could explain differing results in previous studies concerning the response of serum triglyceride concentrations to dietary sucrose in man (Anderson, 1967; Hodges, Krehl, Stone \& Lopez, 1967).

The bi-modal distribution in our patients suggests a genetically determined difference in the concentration of an enzyme taking part in fructose metabolism; it is most unlikely that a dietary difference between the two groups was responsible for this distribution. The results suggest a sex difference between the groups, but this was not significant; our numbers, however, were small. Although the group A patients had a higher mean estimated intake of carbohydrate and sucrose than those in group B, some of the individual patients who fell into group A had low, and some of those in group B had high, intakes of carbohydrate and sucrose. Enzyme induction caused by therapeutic agents was not responsible; one patient in each group was taking a barbiturate at the time of study.

A difference in either fructokinase or liver fructose-I-phosphate aldolase between the groups is unlikely. In essential benign fructosuria where fructokinase is deficient (Froesch, 1966, 1969; Marks \& Samols, 1968), blood pyruvate and lactate concentrations change little after fructose ingestion, but blood concentrations of fructose are higher than normal. In hereditary fructose intolerance in which fructose-I-phosphate aldolase is believed to be deficient (Froesch, 1966, 1969), abnormally high blood fructose concentrations are reached and hypoglycaemia occurs after fructose is given orally. Our results can more readily be explained by differences in the activity of an enzyme further along the fructose metabolic path (Froesch, 1969).

The present study confirms the observation that relatively very small amounts of infused fructose are excreted in the urine (Zöllner et al. 1968); at the infusion rate used this amounts to about $2 \%$. Zöllner et al. (1968) showed that the rate of excretion was approximately constant after the first $120 \mathrm{~min}$ of infusion, and there did not seem to be a renal threshold for fructose.

The responses of blood glucose and insulin concentrations to fructose infused intravenously were similar to those reported in other investigations (Zöllner et al. 1968; Cook, 1969). Zöllner et al. (1968) have shown that fructose given intravenously usually produces an initial rise in glucose whatever the infusion rate. In that investigation infusion rates of $\mathrm{I} \cdot 0-\mathrm{I} \cdot 5 \mathrm{~g} / \mathrm{kg}$ per $\mathrm{h}$, but not $0.5 \mathrm{~g} / \mathrm{kg}$ per $\mathrm{h}$, produced a subsequent fall in glucose concentration of about $6 \mathrm{mg} / 100 \mathrm{ml}$ below the fasting level. Serum inorganic phosphate concentration fell slightly during the infusions in both our groups; the changes were similar to those reported by Smith et al. (1953). The rise in uric acid concentration in our patients was much lower than that reported by Perheentupa \& Raivio (1967).

Addendum. A further five patients have been studied since this investigation was completed. Three fell clearly into group A and two into group B, and the bi-modal distribution of blood lactate and pyruvate is undisturbed. 
We thank Professor Sheila Sherlock and Dr I. A. D. Bouchier for allowing us to study patients in their care, and Professor D. N. Baron and Dr Brenda Ryman for discussion concerning the interpretation of the results. We are grateful to Dr Joyce Bell for the serum triglyceride glycerol estimations and to Miss E. C. Bateman, SRD, for the dietary histories. We gratefully acknowledge financial support from the Ingram Trust.

\section{REFERENCES}

Anderson, J. T. (1967). Am. F. clin. Nutr. 20, 168.

Bell, J. L., Atkinson, S. M. \& Baron, D. N. (I970). F. clin. Path. 23, 509.

Bücher, T., Czok, R., Lamprecht, W. \& Latzko, E. (I963). In Methods of Enzymatic Analysis p. 253 [H. U. Bergmeyer, editor]. New York: Academic Press.

Cook, G. C. (1969). Clin. Sci. 37, 675 .

Cook, G. C. (1970). Clin. Sci. 38, 687.

Fisher, R. A. (1946). Statistical Methods for Research Workers roth ed., p. 70. London: Oliver and Boyd.

Fiske, C. H. \& Subbarow, U. (1925). F. biol. Chem. 66, 375.

Fredrickson, D. S., Levy, R. I. \& Lees, R. S. (1967). New Engl. F. Med. 276, 273.

Froesch, E.R. (1966). In The Metabolic Basis of Inherited Disease p. 124 [J. B. Stanbury, J. B. Wyngaarden and D. S. Fredrickson, editors]. New York: McGraw-Hill.

Froesch, E. R. (r969). F. clin. Path. 22, Suppl. 2, p. 7.

Hales, C. N. \& Randle, P. J. (1963). Biochem. F. 88, 137.

Heinz, F., Lamprecht, W. \& Kirsch, J. (1968). F. clin. Invest. 47, 1826.

Hodges, R. E., Krehl, W. A., Stone, D. B. \& Lopez, A. (1967). Am. F. clin. Nutr. 20 , 98.

Hohorst, H. J. (r963). In Methods of Enzymatic Analysis p. 266 [H. U. Bergmeyer, editor]. New York: Academic Press.

Holdsworth, C. D. \& Dawson, A. M. (1965). Proc. Soc. exp. Biol. Med. 1r8, 142.

Klotzsch, H. \& Bergmeyer, H. U. (1963). In Methods of Enzymatic Analysis p. I 56 [H. U. Bergmeyer, editor]. New York: Academic Press.

Macdonald, I. (1968). Am. F. clin. Nutr. 21, 1366.

Marks, V. (1959). Clinica chim. Acta 4, 395.

Marks, V. \& Samols, E. (1968). In Carbohydrate Metabolism and its Disorders Vol. 2, p. 344 [F. Dickens, P. J. Randle and W. J. Whelan, editors]. New York: Academic Press.

Perheentupa, J. \& Raivio, K. (1967). Lancet ii, 528.

Peters, J. P. \& van Slyke, D. D. (1946). Quantitative Clinical Chemistry: Interpretations Vol. 1, p. 204. London: Baillière, Tindall $\&$ Cox.

Pitts, F. N. Jr \& McClure, J. N. Jr (1967). New Engl. F. Med. 277, I 329.

Praetorius, E. (1963). In Methods of Enzymatic Analysis p. 500 [H. U. Bergmeyer, editor]. New York: Academic Press.

Price-Evans, D. A. (1969). In The Scientific Basis of Medicine Annual Reviews p. 166 . London: Athlone Press.

Smith, L. H., Ettinger, R. H., Seligson, D. \& Lightcap, S. (r953). F. clin. Invest. 32, 273.

Yudkin, J. (1967). Am. F. clin. Nutr. 20, ro8.

Zakim, D. \& Herman, R. H. (1968). Biochim. biophys. Acta 165, 374.

Zöllner, N., Heuckenkamp, P. U. \& Nechwatal, W. (1968). Klin. Wschr. 46, 1300. 